\title{
Market study identifying the feasibility of producing dog food dispensers in Nanchital, Veracruz
}

\section{Estudio de mercado identificando la viabilidad de producir dispensadores de alimento canino en nanchital, Veracruz} MINA, Susana del Carmen*†, GARCÍA-SOSA, Alfonso, GÓMEZ-ARREOLA, Elizabeth and
MORENO-ROBLEDO, María del Carmen

Universidad Tecnólogica del Sureste de Veracruz, Av. Universidad Tecnológica Lote Grande 1, Sin Coloni. Municipio de Nanchital de Lázaro Cárdenas del Rio, Veracruz. C.P. 96360

ID $1^{\text {st }}$ Author: Susana del, Carmen, Mina

ID $1^{\text {st }}$ Coauthor: Alfonso, García-Sosa

ID $2^{\text {nd }}$ Coauthor: Elizabeth, Gómez-Arreola

ID $3^{\text {rd }}$ Coauthor: María del Carmen, Moreno-Robledo

DOI: $10.35429 / J B A B .2019 .4 .3 .22 .27$

Received Mrach 27, 2019; Accepted June 29, 2019

Abstract

Nowadays, families have a pet that represents a part of the love and affection they can give to others, but having this new member implies being responsible regarding its care and feeding, among other aspects. For the owners of a pet it can pose a serious inconvenience, for they need to be very tidy, attentive and comply with the schedules of feeding it. Derived from the above, this research consists of evaluating the feasibility of producing and selling a dog food dispenser that is automatic, programmable and remotely controlled in Nanchital, Veracruz. For this purpose, we conducted a quantitative field research of a descriptive nature with cross section, for it was carried out during a certain period of time. The sample was obtained by consulting an online calculator on the Survey Monkey website with a population of 26,070 people, $5 \%$ error and $95 \%$ confidence level, obtaining a sample of 379 people to be surveyed. (Survey Monkey, 2019). The sampling technique will be randomized, with respondents chosen completely at random. The data collection technique was the survey and the instrument consisted of a 15-question questionnaire. This questionnaire contains multiple choice questions, a Likert scale that allowed us to determine that the production and sale of this dispenser is viable, since most people work and have no way of feeding their pets in the morning and sometimes in the afternoon.

Market study, Feasibility, Food dispenser

\begin{abstract}
Resumen
En la actualidad, las familias tienen una mascota que representa una parte del cariño y amor que pueden dar hacia los demás, pero tener a este nuevo integrante implica ser responsables en su cuidado y alimentación, entre otros aspectos. Para los dueños de una mascota puede significar un serio inconveniente en el que necesite ser muy ordenado, atento y cumplido con los horarios de alimentación de la misma. Derivado de lo anterior, la presente investigación consiste en evaluar la viabilidad de la producción y venta de un dispensador de alimento para perros, que sea automático, programable y controlado remotamente en Nanchital, Veracruz. Para ello, se realiza una investigación de campo de naturaleza cuantitativa, de tipo descriptivo con corte transversal al ser realizado durante determinado periodo de tiempo. La muestra se obtuvo consultando una calculadora en línea de la página web de Survey Monkey con una población de 26,070 personas, $5 \%$ de error y nivel de confianza de $95 \%$ obteniendo una muestra de 379 personas a encuestar. (Survey Monkey, 2019) La técnica de muestreo será aleatoria, en la que los encuestados se eligen completamente al azar. La técnica de recolección de datos es la encuesta y el instrumento es un cuestionario de 15 preguntas. Dicho cuestionario contiene preguntas de opción múltiple, escala de Likert que permitió determinar que sí es viable la producción y venta de dicho dispensador, ya que mayormente las personas trabajan y no tienen forma de alimentar a sus mascotas en el turno matutino y en ocasiones, vespertino.
\end{abstract}

Estudio de mercado, Viabilidad, Dispensador de alimento

Citation: MINA, Susana del Carmen, GARCÍA-SOSA, Alfonso, GÓMEZ-ARREOLA, Elizabeth and MORENOROBLEDO, María del Carmen. Market study identifying the feasibility of producing dog food dispensers in Nanchital, Veracruz. Journal-Business Administration -Marketing; Accounting. 2019. 3-4: 22-27

\footnotetext{
* Correspondence to Author (email: susana.mina@utsv.edu.mx)

$\dagger$ Researcher contributing as first author.
} 


\section{Introduction}

An extensive genetic study has tracked the natural history of the $\operatorname{dog}$ from the grey wolf, dating back to its first contacts with human companions about 33 thousand years ago. (Radford, 2015) In the era of nomadism, the dog gave its company and its visual and olfactory acuity to hunting and gathering. By the fire, it was the guardian of camps during the nights, when all kinds of predators stronger and faster than man prowled. During the most profound social transformation of humanity, the passage from being nomadic gatherers to agrarian sedentarism, dogs were transcendental: they provided the key to the domestication of other animals and were the first shepherds. (Wang, et al., 2016)

The dog was probably the first animal to be domesticated. (National Geographic Press, 2010) Thanks to different researchers we know that the dog has been represented throughout the history of mankind as a guardian, protector, companion and hunter. For many cultures it was a divine gift and was related to death and the forces of evil.

The domestication of animals is considered one of the milestones of humanity, with an impact similar to that of the invention of the wheel, since it facilitated field work, shelter and transport. (Alba, 2015)

Today, families have a pet because they can give their love to someone else. In addition to providing companionship and improving harmony in the home, canines often make household members feel protected from burglaries. But to have this new member represents a responsibility for the family nucleus that implies not to neglect it, as well as, to satisfy its basic necessities, such as its daily feeding. This can represent a serious inconvenience for it requires the owner to be very tidy, attentive and comply with food schedules.

However, in the modern world, where everyone has daily responsibilities, one cannot be beside its pet all the time to ensure that its food is adequate. Poor nutrition in pets can lead to diseases that affect their metabolism and the development of their bones and organs at an early age.
Among the effects related to poor
nutrition are the following: obesity, cardiovascular problems, respiratory problems, sweating, deficiency in bone development, weight loss, anemia, increased urination, diarrhea, bone decalcification, especially in the spine of the dog, accelerated growth of the animal causing malformations in their joints, allergies, respiratory problems, vomiting, gastritis, among others.

So, in terms of nutrition, the following conditions must be guaranteed: that it is administered in the right proportions, that it is provided at regular times and that it contains the necessary nutrients for the correct development of the animal. In addition, the owner must always ensure that his or her pet actually consumes the food provided.

Acquiring a pet is a big responsibility and people should think carefully before making that decision. It is a creature that demands time and attention. Therefore, the owner must properly manage their resources to provide the right care for their pet without neglecting daily life responsibilities.

The overall goal of this research is: To evaluate the feasibility of producing and selling an automatic, programmable and remotely controlled dog dispenser in Nanchital, Veracruz. Other objectives are: To conduct the data collection instrument; identify the population and sample for market research; analyse the data collected through the applied instrument.

\section{Methodology}

The research is quantitative in nature, descriptive in type and the research design is non-experimental with a cross section.

Research hypothesis: It is feasible to develop a food dispenser for the inhabitants of Nanchital, Ver.

Null hypothesis: The elaboration of a food dispenser for the inhabitants of Nanchital is not feasible, Ver.

The population considered for the application of the questionnaire consists of all the people of Nanchital de Lázaro Cárdenas del Río. Data on the number of people was obtained through INEGI. 
The unit of analysis is the inhabitants of that city. INEGI (http://www.beta.inegi.org.mx/app/indicadores/ \#)

The sample was obtained by consulting an online calculator on the Survey Monkey website. It is called a sample because it represents only part of the group of people (or population) whose opinions or behavior are of interest to the subject of the study. (Survey Monkey, 2018)

The following data was input into the calculator:

- $\quad$ The total population is: 26,070 people

- $\quad 5 \%$ error is prevented

- The common confidence level used is 95\%.

This resulted in a sample of 379 people to be surveyed. The sampling technique was random, in which respondents were chosen completely at random.

The data collection technique was the survey and the data collection instrument consisted of a 15-question questionnaire (including one for respondent suggestions). This questionnaire had multiple choice questions, Likert scale, in order to determine if product development was feasible.

\section{Results}

The fourteen questions are represented in each chart below: Question 1 (Figure 1) shows the first question referring to the existence of pets (dogs) in the home. 80\% indicated that they do have pets and $20 \%$ answered that they do not.

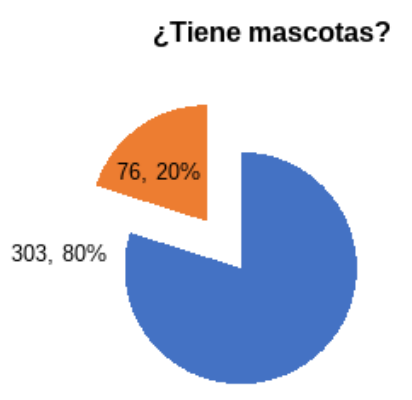

Figure 1 Question 1. 2019 (Prepared by the authors)
Question 2 (Figure 2) inquired about the exact number of canines in the household. $45 \%$ have one, $30 \%$ have two and $25 \%$ have more than two.

¿Cuántos perros tiene en casa?

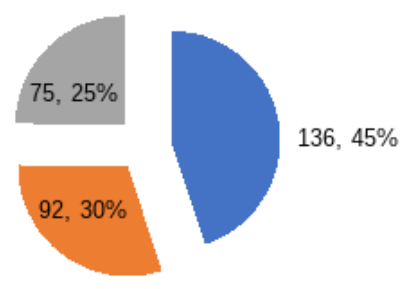

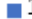
$=2$

Figure 2 Question 2. 2019 (Prepared by the authors)

In question 3 (figure 3) the respondent expressed the importance of the pet in their life. $64 \%$ said it was very important, $30 \%$ important, $5 \%$ not so important and $1 \%$ not important at all.

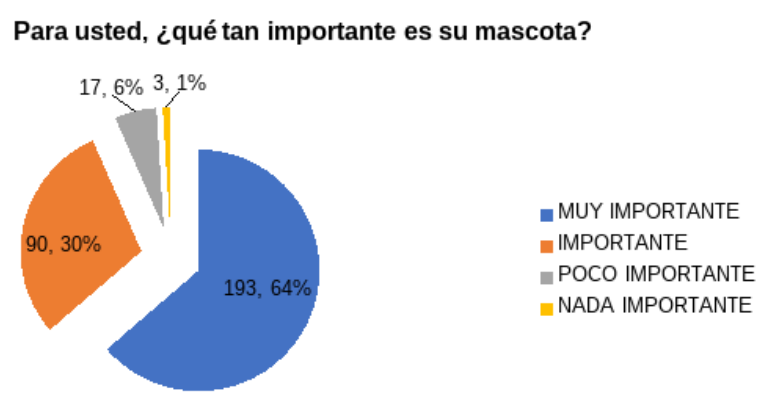

Figure 3 Question 3. 2019 (Prepared by the authors)

Question 4 (Figure 4) refered to feeding at set times. $47 \%$ said they never fed it at set times, $38 \%$ rarely, $7 \%$ occasionally, $5 \%$ frequently and $3 \%$ very frequently.

¿Lo alimenta en los horarios establecidos?

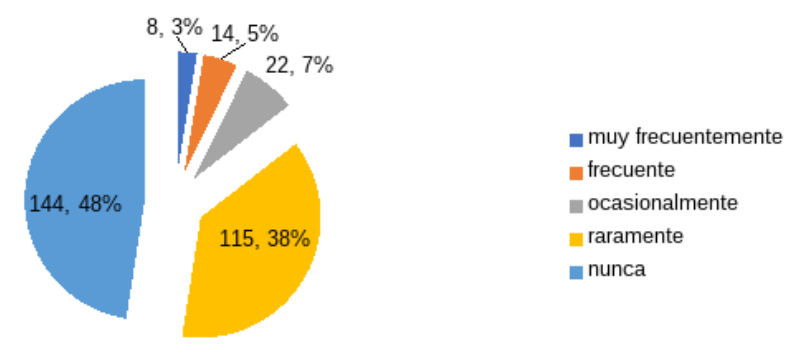

Figure 4 Question 4. 2019 (Prepared by the authors)

Question 5 (figure 5) allowed us to know if the pet is left alone during the day or at night, $39 \%$ said that they do so rarely, $26 \%$ occasionally, $17 \%$ never, $13 \%$ frequently and $5 \%$ very frequently. 
¿Suele usted dejar solo a su mascota durante el día o la noche?

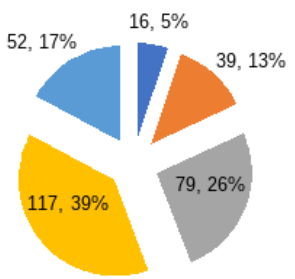
- FRECUENTEMENTE OCASIONALMENTE $\because$ RARAMENTE $\because$ NUNCA

Figure 5 Question 5. 2019 (Prepared by the authors)

Question 6 (Figure 6) inquired if there is anyone else who provides food when the owner is not there. $26 \%$ say rarely, $23 \%$ occasionally, $19 \%$ frequently, $17 \%$ very frequently and $15 \%$ never.

¿Existe alguna persona que le proporcione comida cuando usted no está?

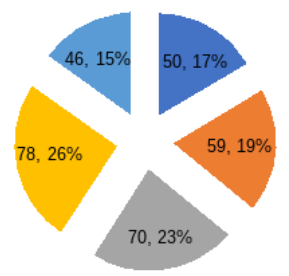

- MUY FRECUENTEMENTE - FRECUENTE - OCASIONALMENTE - RARAMENTE - NUNC

Figure 6 Question 6. 2019 (Prepared by the authors)

In question 7 (figure 7), the purpose was to find out how often the pet is cared for by another person on a monthly basis. $68 \%$ indicated that their pet is rarely cared for by anyone else, $18 \%$ occasionally, $10 \%$ frequently, $4 \%$ very frequently.

Durante el mes, ¿con qué frecuencia es atendida su mascota por otra persona?

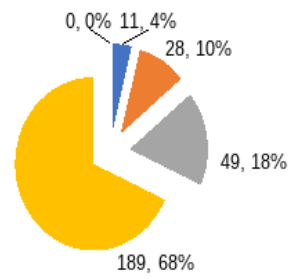

MUY FRECUENTEMENTE - FRECUENTEMENTE -OCASIONALMENTE - RARAMENTE $\because$ NUNCA

Figure 7 Question 7. 2019 (Prepared by the authors)

Question 8 (figure 8) aimed to find out if the canine is fed adequately, with $66 \%$ indicating that they rarely do so, 30\% never, $2 \%$ occasionally and $2 \%$ frequently.

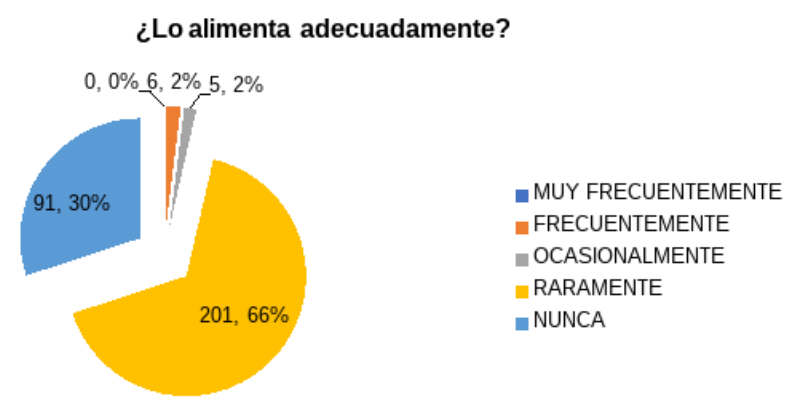

Figure 8 Question 8. 2019 (Prepared by the authors)

Question 9 (Figure 9) inquired whether the person knows of any dog food dispensers to which $90 \%$ said no and $10 \%$ said yes.

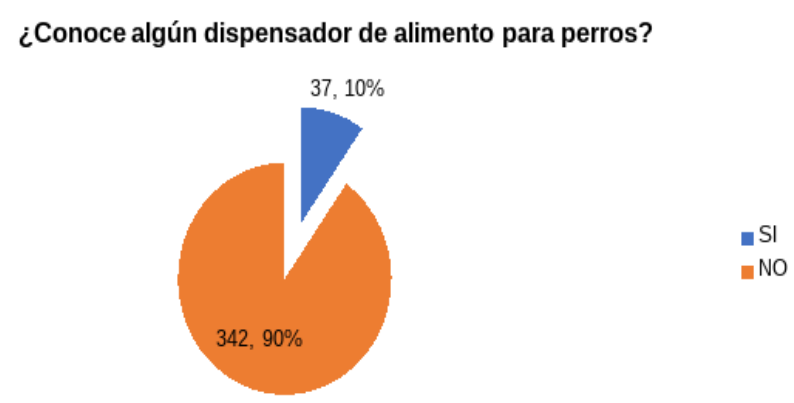

Figure 9 Question 9. 2019 (Prepared by the authors)

Question 10 (Figure 10) asked to whether the owner had ever used a dog food dispenser. $98 \%$ said no and $2 \%$ yes.

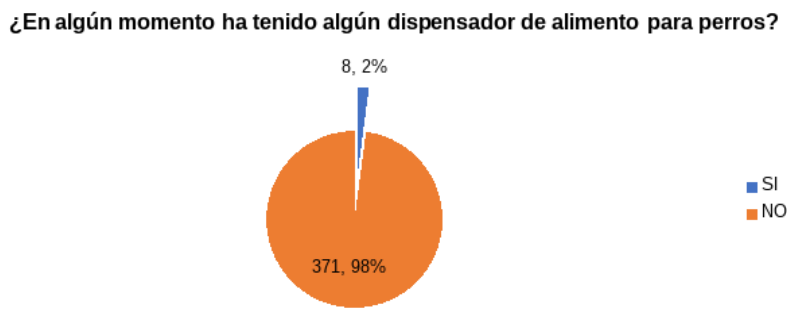

Figure 10 Question 10. 2019 (Prepared by the authors)

Question 11 (Figure 11) inquired whether the person would trust the use of such a dispenser to feed their pet. $69 \%$ indicated that they would, $22 \%$ perhaps, and $9 \%$ would not.

¿Confiaría en la utilización de un dispensador para alimentar a su mascota?

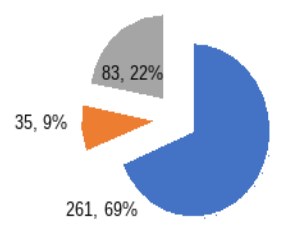

Figure 11 Question 11. 2019 (Prepared by the authors) 
Question 12 (Figure 12) revealed whether people would be willing to buy the product. $83 \%$ would, $13 \%$ might and $4 \%$ would not.

¿Estaría dispuesto a comprar un alimentador?

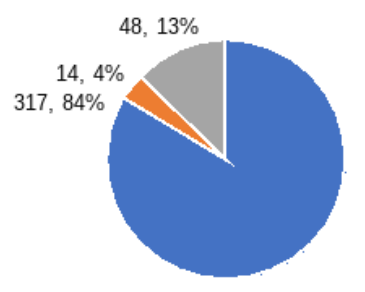

$-\mathrm{SI}$

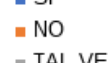

- TAL VEZ

Figure 12 Question 12. 2019 (Prepared by the authors)

Question 13 (Figure 13) asked the average amount a person would be willing to pay for a food dispenser. $41 \%$ would pay up to $\$ 300$ pesos, $23 \%$ would pay up to $\$ 500,21 \%$ would pay up to $\$ 200$ and $1 \%$ would pay up to $\$ 1000$.

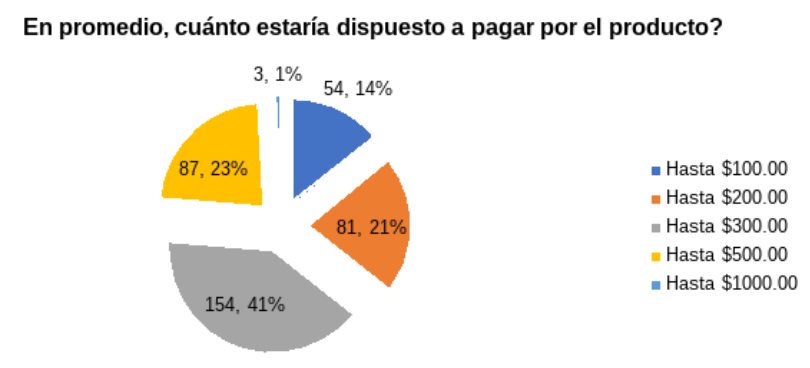

Figure 13 Question 13. 2019 (Prepared by the authors)

Question 14 (figure 14) identified where people would be willing to purchase the product. $51 \%$ would buy it from veterinarians, $44 \%$ from shopping centres and 5\% from others (convenience stores and the factory itself).

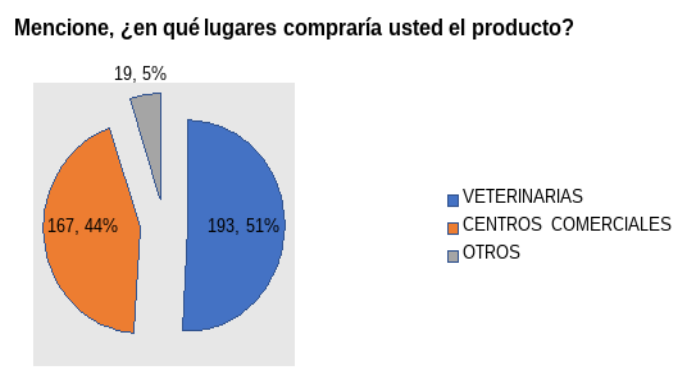

Figure 14 Question 14. 2019 (Prepared by the authors)

The following is an analysis of the most relevant questions at the time of the survey: home.

$80 \%$ have at least one or two dogs in their
Of these, $94 \%$ said that a canine is important or very important in their home and in their daily life. At the same time, $85 \%$ indicated that they rarely or never feed it during established hours due to work or personal reasons.

It was found that in $68 \%$ of cases, their pet is rarely cared for by someone else. From this, it also follows that $96 \%$ rarely or never feed the dog adequately.

90\% of people do not know of any dog food dispensers. In addition, $98 \%$ of respondents have not used a dog food dispenser at some point, however, $69 \%$ would rely on using a dog food dispenser to feed their pet with the likelihood increasing to $91 \%$.

Therefore, $83 \%$ would be willing to purchase the product with the probability increasing to $96 \%$.

The amount they would be willing to pay for the dispenser is $\$ 300.00$ pesos although others expressed the need to pay up to $\$ 500.00$ if that implies greater security in the feeding of the canine.

The places where it would be easy for them to acquire the product are veterinarians and shopping malls.

Derived from the above, the research hypothesis is fulfilled, which indicated that it is feasible to produce and sell a dispenser for dogs that is automatic, programmable and remotely controlled in Nanchital, Veracruz.

The design suggestions are: adequate size and resistance.

Other suggestions are: safe handling, easy to use, easy store location and affordable price.

By identifying that people would mostly buy the product in veterinarians or shopping centers, it is concluded that it is not necessary to install a company dedicated to the unique sale of the product, rather, the factory can have a point of sale with distribution of the product to retailers and wholesalers, supplying the latter within the city. 
After that, the market can be expanded and the state with its cities and municipalities can be considered to offer the product.

\section{References}

Alba. (April 29, 2015). Petsonic. Retrieved from Petsonic: https://www.petsonic.com/blog/elorigen-del-perro/

http://www.beta.inegi.org.mx/app/indicadores/\# . (s.f.).

INEGI. (2009). Instituto Nacional de Estadística y Geografía. Retrieved from Instituto Nacional de Estadística y Geografía: http://www.beta.inegi.org.mx/app/areasgeografi cas/?ag=30\#

Radford, T. (December 15, 2015). The Guardian. Retrieved from The Guardian: https://www.theguardian.com/science/2015/dec /15/dog-dna-study-reveals-the-extraordinaryjourney-of-mans-best-friend

Redacción National Geographic. (September 5, 2010). National Geographic. Retrieved from National Geographic: https://www.nationalgeographic.es/animales/pe rro-domestico

Survey Monkey. (2018). Survey Monkey. Retrieved from Survey Monkey: https://es.surveymonkey.com/mp/sample-sizecalculator/?iv_=_iv_p_1_a_148340984_g_716 0803184_c_198762940019_k_m_b_w_dsa56246412584_n_g_d_c_v__1_t_r_1t1_x_y_ _f_o_z__i_j__s_e_h_1031288_ii_vi_\& utm_source $=$ adwords\&utm_medium $=$ ppc\&utm _term=\&utm_netwo

Survey Monkey. (2019). Survey Monkey. Retrieved from Survey Monkey: https://es.surveymonkey.com/mp/sample-sizecalculator/

Wang, G.-D., Zhai, W., Yang, H.-C., Wang, L., Zhong, L., Liu, Y.-H., . . . Zhang, Y.-P. (2016). Out of southern East Asia: the natural history of domestic. China: Open.

\section{Annexes}

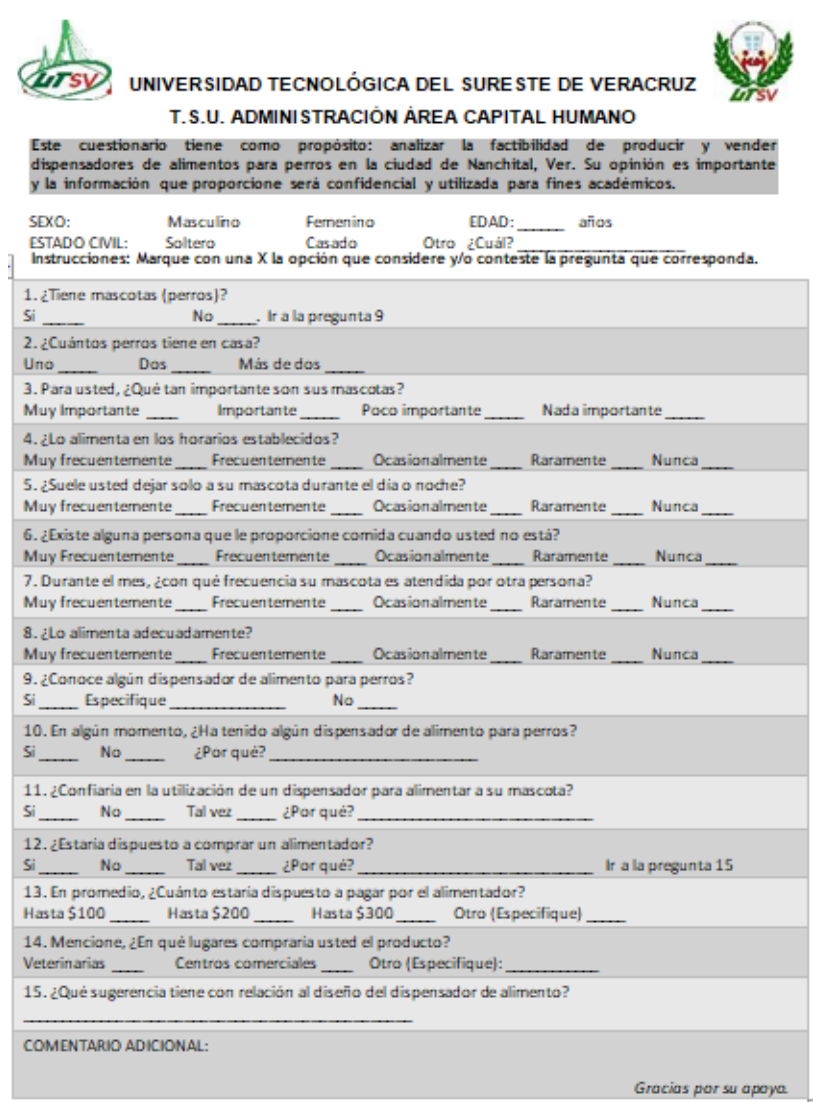

